\title{
Die Persoon van die Heilige Gees
}

\author{
J J ENGELBRECHT (Jr)
}

Die Bybel is ' $n$ bundel geskrifte waarvan ons in die kerk glo dat hulle onder leiding van die Heilige Gees ontstaan het. Ons glo verder dat hulle in een bundel saamgevoeg is om te dien as hoogste norm vir die geloof, leer en lewe van die mense wat in die ware God glo.

Wanneer 'n mens wil vasstel wat die Bybel byvoorbeeld oor die Heilige Gees of oor die kerk sê, duik daar gou 'n probleem op: Die Bybel is nie soos ' $n$ ensiklopedie saamgestel nie - 'n mens kan nie met behulp van ' $n$ alfabetiese inhoudsopgawe gou by die letter " $\mathrm{H}$ " vir "Heilig" of by "G" vir "Gees" verwysings na bepaalde bladsye kry waar dan 'n netjiese uitgewerkte verduideliking oor die persoon en werk van die Heilige Gees gevind kan word nie. Die inligting oor die Heilige Gees is in stukkies en brokkies op duisend-en-een plekke dwarsdeur de Bybel opgeteken. Dit verg moeisame studie om dit alles op te spoor en die baie drade by mekaar te kry.

Gelukkig het die kerk deur die eeue gesorg dat daar in die belydenisskrifte kernagtige samevattings staan van die wyse waarop die kerk die Bybelse boodskap op bepaalde punte verstaan.

Die Bybel is nie ' $n$ breedvoerige uiteensetting van die belydenisskrifte nie, die Bybel moet ook nie in die lig van die belydenis verstaan word nie, maar omgekeerd: Die belydenis moet altyd weer aan die Bybel getoets word en in die lig van die Bybel uitgelê word. As dit sou blyk dat die belydenisskrif in die een of ander opsig in stryd is met die Bybelse leer, moet die belydenis verander word; nie die Bybel nie!

Hier dink ons onder andere aan die Nederlandse Geloofsbelydenis en die bekende Heidelbergse Kategismus, om nie eers te praat van die veel ouer sogenaamde ekumeniese belydenisse soos die Twaalf Artikels (Apostolicum), die Niceense Geloofsbelydenis (Symbolum Niceno-Constantino-politanum of die Credo) en die belydenis van Athanasius nie.

Nou gaan ons kortliks aandag skenk aan die persoon van die Heilige Gees. Vir die doel het ek noukeurig probeer luister na wat die Bybel oor hierdie onderwerp sê, en ook na die wyse waarop die kerklike belydenisskrifte die Bybel oor hierdie saak verstaan. Hoewel ek my in wat ek gaan sê nie absoluut gebonde ag aan die patroon van enige belydenisskrifte nie, neem ek beslis met waardering daarvan kennis. 


\section{Die Heilige Gees is 'n persoon}

Die term "persoon" word so ver ek weet nêrens in die Bybel in verband met die Vader of die Seun of die Heilige Gees gebruik nie. Dit is ' $n$ term wat na die tot standkoming van die Nuwe Testament in die teologie gebruiklik geword het. Dit is en word gebruik om te onderskei tussen die Vader en die Seun en die Heilige Gees. Van elkeen van hierdie Drie geld dat Hy 'n persoon is, dus iemand wat uit eie magsbevoegdheid "ek" kan sê en vanuit hierdie magsbevoegdheid handelend en sprekend optree. Johannes 14:16 is 'n teks wat aangehaal word ter stawing van die stelling dat die Heilige Gees 'n persoon in bogenoemde sin is. In die Blye Boodskap lui daardie teks so: "Ek sal die Vader vra, en Hy sal vir julle 'n ander Voorspraak stuur om vir ewig by julle te wees, naamlik die Gees van die Waarheid, ..." Johannes 16:14 spreek in hierdie verband nog duideliker taal as die evangelis vertel dat Jesus aangaande die Heilige Gees gesê het: "Hy sal my verheerlik, want wat Hy van my ontvang, sal Hy aan julle verkondig." Sulke dinge kan tog nie van 'n onpersoonlike mag gesê word nie, al weet ons van so 'n stylfiguur soos personifikasie.

Ook in Efesiërs 4:30 kan die Heilige Gees nie maar sommer as 'n onpersoonlike mag verstaan word nie. Paulus beveel immers sy lesers om die Heilige Gees nie te bedroef nie.

Matteus 12:31 waarin daar sprake is van sondig teen die Heilige Gees, en in Handelinge 7:51 wat uit Jesaja 66:1 en 2 aanhaal, waar sy hoorders verwyt word dat hulle altyd die Heilige Gees weerstaan, word ook soms bygehaal ter stawing van die stelling dat die Heilige Gees 'n persoon is en nie bloot 'n onpersoonlike mag nie.

Die feit dat die Heilige Gees ook soms 'n krag (dunamis) van God genoem word, hoef nie hiermee in stryd te wees nie.

\section{Die Godheid van die Heilige Gees}

Ons het so pas daaroor duidelikheid gekry dat die Heilige Gees 'n persoon is en nie ' $n$ dier of ' $n$ ding nie. ' $n$ Volgende belangrike vraag wat aandag moet kry, is of die Heilige Gees 'n geskape wese soos'n mens of 'n dier of ' $n$ ding is.

Was daar met ander woorde ooit ' $n$ tyd toe die Heilige Gees nog nie bestaan het nie? Of is Hy dalk 'n ongeskape wese, dus God?

Die Bybel gee verrassende inligting hieroor. Ons noem enkele voorbeelde: In die Ou Testament staan daar in Jesaja 6:8-10 “Daarop hoor ek die stem van die Here (Adonai) wat sê: Wie sal Ek stuur? En wie sal vir ons gaan? Toe antwoord ek (dit wil sê die profeet): "Hier is ek, stuur my. En hy (dit wil sê die Here) het gespreek: Gaan sê aan hierdie volk: Hoor altyddeur, maar verstaan nie ..."

Volgens die Jesaja teks in die Ou Testament is daar geen twyfel oor 
dat dit die Here is wat met en deur die profeet praat nie. Maar hoor nou wat sê die skrywer van Handelinge in die Nuwe Testament wanneer hy daardie gedeelte uit Jesaja aanhaal: "Hoe waar is dit tog wat die Heilige Gees by monde van die profeet Jesaja vir julle voorvaders gesê het. Hy (= die Heilige Gees) het gesê: "Gaan na hierdie volk en sê vir hulle ... (Handelinge 28:25-27).

Ook uit Markus 12:36 en Handelinge 11:28 blyk dat waar die Ou Testament sou sê dat die Here dit of dat sê, die Nuwe Testament meermale sê dat die Heilige Gees die betrokke profeet lei of deur hom spreek.

In 1 Korintiërs 3:16 vra Paulus vir die Korintiërs of hulle nie weet dat hulle' $n$ tempel van God is en dat die Gees van God in hulle woon nie. In hoofstuk 6:18 en 19 van dieselfde brief waarsku Paulus egter die gemeente teen 'n growwe vorm van seksuele losbandigheid en stel in daardie verband die vraag: "Of weet julle nie dat julle liggaam 'n tempel is van die Heilige Gees wat in julle is, wat julle van God het, en dat julle nie aan julself behoort nie" (vers 19).

Uit bogenoemde gedeeltes van die Bybel en uit ander Bybelgedeeltes wat ons nie genoem het nie, moet ons aflei dat van die Heilige Gees gepraat word soos van God, en nie soos van 'n geskape wese nie.

Volgens sommige geleerdes is die Heilige Gees nie 'n aparte Iemand nie, maar slegs God wat geestelik werk en wat geestelik teenwoordig is. Daar is ' $n$ waarheidselement in hulle standpunt, want die Heilige Gees tree nooit los van die Vader en die Seun op nie. Tog moet uit Skrifgedeeltes soos byvoorbeeld Johannes 14:16 en 16:14 afgelei word dat die Heilige Gees onderskei moet word van die Vader en die Seun: Jesus sal die Vader bid om vir die dissipels 'n ander Voorspraak te stuur, naamlik die Heilige Gees. Volgens die tweede genoemde gedeelte uit Johannes, sal die Heilige Gees die dinge wat Hy van Jesus ontvang, aan die dissipels verkondig (vergelyk ook Johannes 16:15).

Hier kan ook gewys word op die doop van Jesus. Volgens Matteus het die Gees van God soos 'n duif op Jesus (die Seun) neergedaal en toe het 'n stem uit die hemel gesê: "Dit is my geliefde Seun, in wie Ek my verheug" (Matt 3:16, 17 vergelyk ook Johannes 1:32, 33)

\section{Die Heilige Gees is deel van die Drie-enige God}

Tot dusver het ons agtergekom dat die Heilige Gees 'n persoon is wat uit eie magsbevoegdheid dinge kan doen en sê. Ons het tot die gevolgtrekking gekom dat die Bybel oor die Heilige Gees nie praat soos oor 'n mens nie, maar soos oor God. Derdens het ons vasgestel dat die Bybel onderskei tussen die Vader en die Seun en die Heilige Gees. Dink in hierdie verband aan die genoemde gedeeltes uit Mat- 
teus en Johannes. Dit is byvoorbeeld nie die Vader wat op die Pinksterfees oor die gelowiges uitgestort is nie (Hand 2) maar die Heilige Gees; dit is nie die Heilige Gees wat uit die dode uit opgestaan het nie, maar die Seun. (vergelyk ook Matteus 28:19, II Korintiërs 13:13).

Intussen het ons ongemerk gekom by die sogenaamde leer oor die Drie-enige God, of die Triniteitsleer. Hierdie leer is 'n swakke menslike poging om die Bybelse prediking oor die verhouding tussen die Vader en die Seun en die Heilige Gees, kernagtig te probeer formuleer. Dit moet onthou word dat die Bybel nêrens in soveel woorde'n leer oor die Drie-enige God formuleer nie, hoewel die saak oorvloediglik in die Bybel ter sprake kom. Enersyds is die Bybel daar duidelik oor dat daar net een God is en nie twee of meer nie. Hierdie God duld ook geen ander gode nie (vergelyk die eerste gebod). Tog het reeds geblyk dat die Bybel tussen die Vader en die Seun en die Heilige Gees onderskei. Elkeen van hierdie Drie word in die Bybel soos God aanbid en verheerlik. In die Onse Vader word (Matt 6:9) Die Vader in die gebed aangeroep; Jesus keer dit goed dat Tomas Hom na sy opstanding uit die dode, aanbid en aanspreek as "My Here en my God". (Joh 20:28); in die berig aangaande Ananias en Saffira (Hand 5) word 'n leuen wat vir die Heilige Gees vertel word, gelyk gestel aan 'n leuen wat vir God vertel word met ewe verskriklike gevolge vir die skuldige.

'n Mens kry die indruk dat die Bybelskrywers hulle nie veel ge$k w e l$ het oor die probleem van die verstaanbaarheid van die onderlinge verhouding tussen die Vader en die Seun en die Heilige Gees nie. Dit het eers in later eeue 'n probleem begin word toe dwaalleraars die ewige Godheid van die Seun of van die Heilige Gees ontken het of geleer het dat hierdie Drie verskillende Gode is.

In stryd teen hierdie dwaalleringe of ketterye is die kerk gedwing om sy standpunt oor hierdie saak te probeer formuleer. Dit moes gebeur met behulp van terme wat vir die mense van daardie tyd verstaanbaar was. So het die sogenaamde Triniteitsleer waarvolgens God een in wese, maar onderskeie in drie persone is, ontstaan.

Eintlik is hierdie saak te ingewikkeld vir ons kleine menslike verstandjies. Daarom probeer ons dit deur middel van enkele beelde wat geleerdes vir die doel gebruik het, 'n bietjie meer verstaanbaar maak.

Die eerste beeld wat genoem word is baie oud. Dit is ' $n$ beeld wat teen die jaar $200 \mathrm{nC}$ deur Tertullianus gebruik is. Hy het hierdie beeld aan die regswêreld ontleen om die verbinding van die drie persone in die een substansie te verduidelik. Substansie word dan voorgestel deur' $n$ eiendom of besitting wat deur die drie persone ten volle, ongedeeld en gesamentlik besit word (sonder separatio, divisio, disperio of distinctio). 
Die eenheid van God lê dus in die substansie of wese, die status, mag en heerskap.

Op die beswaar dat "Een ... nie drie en drie (nie) een (is) nie", antwoord A van Selms: "Maar hoe is dit by die eerste wat God volgens die Bybel geskape het, die lig? Ons onderskei ligbron, ligstraal en die beeld van die lig wat gevorm word op ons netvlies. Tog sê ons gewoonlik: Ek sien 'n lig. Hoeveel ligte? Een. Waarom onderskei ons dan die drie as daar maar een is? Omdat hierdie een drie is en drie een is.

'n Mens sou nog kon praat oor die Heilige Gees as 'n gawe aan die gemeente, die Heilige Gees as eerste paaiement van die voordele wat die gelowiges om Christus ontwil in die hiernamaals sal geniet, ensovoorts. By hierdie geleentheid wil ek egter nog net een paragrafie as slot byvoeg. Die bedoeling is immers nie om in een enkele artikel as't ware 'n handboek vir die leer oor die Heilige Gees daar te stel nie.

Op hierdie stadium wil ek nog net daarop wys dat $u$ dit volgens die Bybel aan die werking van die Heilige Gees te danke het as $u$ Jesus Christus as $u$ Verlosser leer ken het; $u$ het dit ook aan die Heilige Gees te danke dat $u$ die vrymoedigheid kan hê om in hierdie deurmekaar en geterroriseerde wêreld God te kan aanroep as "Onse Vader wat in die hemel is." Aan hierdie dinge, naamlik die werk van die Heilige Gees, word in die ander artikels meer aandag geskenk. 